\title{
International differences in the family gap in pay: the role of labor market institutions
}

Citation for published version (APA):

Dupuy, A., \& Fernandez-Kranz, D. (2007). International differences in the family gap in pay: the role of labor market institutions. Researchcentrum voor Onderwijs en Arbeidsmarkt, Faculteit der Economische Wetenschappen. ROA Research Memoranda No. 5 https://doi.org/10.26481/umaror.2007005

Document status and date:

Published: 01/01/2007

DOI:

10.26481/umaror.2007005

Document Version:

Publisher's PDF, also known as Version of record

\section{Please check the document version of this publication:}

- A submitted manuscript is the version of the article upon submission and before peer-review. There can be important differences between the submitted version and the official published version of record.

People interested in the research are advised to contact the author for the final version of the publication, or visit the DOI to the publisher's website.

- The final author version and the galley proof are versions of the publication after peer review.

- The final published version features the final layout of the paper including the volume, issue and page numbers.

Link to publication

\footnotetext{
General rights Owners
rights.

- You may freely distribute the URL identifying the publication in the public portal. please follow below link for the End User Agreement:

www.umlib.nl/taverne-license

Take down policy

If you believe that this document breaches copyright please contact us at:

repository@maastrichtuniversity.nl

providing details and we will investigate your claim.
}

Copyright and moral rights for the publications made accessible in the public portal are retained by the authors and/or other copyright owners and it is a condition of accessing publications that users recognise and abide by the legal requirements associated with these

- Users may download and print one copy of any publication from the public portal for the purpose of private study or research.

- You may not further distribute the material or use it for any profit-making activity or commercial gain

If the publication is distributed under the terms of Article $25 \mathrm{fa}$ of the Dutch Copyright Act, indicated by the "Taverne" license above, 


\title{
International Differences in the Family Gap in Pay: the Role of Labor Market Institutions
}

\author{
Arnaud Dupuy \\ Daniel Fernández-Kranz
}

ROA-RM-2007/5

September 07

Research Centre for Education and the Labour Market

P.O. Box 616

6200 MD Maastricht

The Netherlands

E-mail: $\quad$ mailto:secretary@roa.unimaas.nl

Internet: http://www.roa.unimaas.nl

Maastricht University

Faculty of Economics and Business Administration 
The ROA Research Memorandum Series was created in order to make research results available for discussion, before those results are submitted for publication in journals. 
ROA-RM-2007/5 » http://www.roa.unimaas.nl/resmem.htm

\section{Abstract}

\section{International Differences in the Family Gap in Pay: the Role of Labor Market Institutions ${ }^{1}$}

Using microdata for 35 countries over the period 1985-1994-2002 we find that labor market institutions traditionally associated to more compressed wage structures are associated to a higher family gap. Our results indicate that these policies reduce the price effect of having children but aggravate the human capital loss due to motherhood. We also find evidence that policies that help women continue in the same job after childbirth decrease the family gap. Of all the countries we study, mothers in Southern Europe suffer the biggest family gap and our analysis indicates that this is due to the bad combination of labor market policies in these countries. Our results are robust to specification changes and indicate that the main reason mothers lag behind other women in terms of earnings is the loss of accumulated job market experience caused by career breaks around childbirth.

JEL Codes: J31; J60

Arnaud Dupuy

ROA

P.O. Box 616

6200 MD Maastricht

a.dupuy@ roa.unimaas.nl
Daniel Fernández-Kranz

Business Administration and

Economics Department

Saint Louis University Madrid

Avd. Del Valle 34

Madrid 28003 Spaint

fernandezd@madrid.slu.edu

1. We are grateful to Jane Waldfogel and participants at the ROA Labor Economics Seminar, Maastricht University for valuable suggestions and advice. We are indebted to the Zentralarchiv für Empirische Sozialforschung at the University of Cologne, Germany, for making the ISSP data available. All errors are our own. 



\section{Introduction}

In the last thirty years the Spanish fertility rate has decreased fifty percent and is today one of the lowest worldwide. The Spanish population froze between 1989 and 1993 and decreased in absolute numbers in 1991 (I.N.E. 2006). At the same time, a growing percentage of young and middle age Spanish women joined the labor market, in an astonishing increase of the female participation rate from $28.8 \%$ in 1975 to $45.7 \%$ in 2005 (I.N.E. 2006). The case of Spain clearly suggests that the functioning of labor markets is an important determinant of the cost of having children and of fertility decisions. It has been argued for example that high unemployment and unstable contracts, common in Southern Europe, raise the cost of having children and depress fertility, particularly among younger women (Adserà 2002). More generally, the different institutional framework of labor markets across countries can be an important determinant of the differences in the labor cost of having children internationally and there is evidence that the wage penalty associated to motherhood varies quite substantially across countries. For example, among the thirty five countries we analyze in this study the mean and the standard deviation of the estimated family gap in earnings - the difference in earnings between mothers and other women is .21 and $.18 \log$ points respectively. In this paper we investigate the role of labor market institutions to explain the differences in the earnings gap between mothers and non-mothers internationally.

Several studies have looked at the family gap internationally (Davies \& Pierre 2005, Todd 2001, Harkness \& Waldfogel 1999, Sigle-Rushton \& Waldfogel 2004). These studies find that the family gap varies considerable across countries, but none has looked in detail at the role of labor market institutions in explaining these differences. Gornick et al. (1997) compares fourteen OECD countries, as of the middle-to-late 1980s, with respect to their provision of policies that support mothers' employment, but that study does not draw a link between these institutions and the family gap. Our paper is the first attempt to study empirically the relationship between the family gap and the regulation of labor across a large sample of countries. We calculate the family gap in thirty five different countries and we test the relationship between these family gaps and the different regulation of labor in each country during the period 19851994-2002. 
The effect of labor market institutions on the family gap is ambiguous. Reasons for the difference in earnings between mothers and non-mothers include a price effect, a human capital effect and a heterogeneity effect (Waldfogel 1998b). According to the price effect, one reason mothers lag behind other women in terms of earnings is that firms pay women with children a lower wage compared to other women, even after controlling for individual characteristics. This price effect could reflect the lower effort exerted by mothers in their jobs or instead could be due to employers' discrimination against mothers. According to the human capital effect of motherhood another reason there is a gap between the earnings of mothers and non-mothers is that women with children accumulate less human capital (job market experience) because they interrupt their careers to take care of children (Erosa et al. 2002).

Labor market institutions such as the minimum wage and collective bargaining coverage can attenuate the price effect of motherhood by setting a floor on wages received by mothers. In the case of the human capital effect, the impact of labor market institutions on the family gap is more ambiguous. ${ }^{23}$ Labor market institutions such as parental leave and job protection regulations can reduce the family gap by lowering the frequency of job transitions around childbirth. However, too generous parental leave can lead to long periods out of employment and a large loss of experience (Waldfogel 1998), and too strict firing restrictions or too high wage floors can lead to unemployment (Nickell 1997, Siebert 1997), which would increase the duration of job interruptions. We find that tenure enhancing institutions, such as parental leave, job protection regulations and restrictions to the use of temporary contracts, are associated to a lower family gap. We also find that wage compressing institutions, such as

2. Lundberg \& Rose (2000) find that job interruptions due to motherhood cause the time devoted to work by the husband to increase, partially offsetting the negative effect on the mother's earnings.

3. A third explanation for the family gap results from an heterogeneity bias, since it is possible that being a mother is correlated with other variables, unobservable, that affect the earnings potential of a particular woman. In this case, the estimated family gap would simply reflect the effect of these unobservable variables on the earnings potential of mothers but not necessarily the fact that having children depresses wages in itself. In this paper we use cross-sectional data and hence we are not able to quantify the extent of heterogeneity bias in our sample. However, since our analysis consists of a cross country comparison, all we need is that the correlation between unobservable variables and motherhood, as well as the distribution of the former in the population, is similar across countries. 
unemployment benefits and trade union coverage, are instead associated to a larger family gap. Furthermore, our results indicate that this type of policies reduce the price effect of motherhood but are associated to a larger human capital loss.

Our paper relates also to the literature that has studied the link between labor market institutions and the gender gap. We use the same data set and methodology to estimate the family and the gender gaps, which allows us to compare the effect of the same group of labor market institutions on each of these gaps. In a study of the gender gap in twenty two countries, Blau and Kahn (2003) use the same dataset as ours and find that labor market institutions that compress the wage structure overall also tend to reduce the wage gap between men and women. Other studies have concluded that a reduction of the family gap would cause the gender gap to fall as well (Waldfogel 1998, Waldfogel 1998b, Millimet 2000) since a large percentage of women are also mothers (60\% in our sample).

We argue that labor market institutions can have very different effects on the earnings differential between men and women on the one hand and women with children and non-mothers on the other. One key difference between mothers and non-mothers is that mothers' labor turnover is much higher than that of nonmothers (Anderson et al. 2003, Data \& Smith 2002, Phipps et al. 2001, Klerman \& Leibowitz 1994). The literature has also found a close link between past decisions about labor market participation and women's current wage level (Eckstein \& Wolpin 1989, Altû \& Miller 1998) with a particularly strong effect in the case of job interruptions due to motherhood (Gronau 1988, Korenman \& Neumark 1992). Furthermore, these effects tend to persist in time because turnover probabilities depend negatively on tenure and experience (Topel \& Ward 1992). All this literature suggests that tenure enhancing policies will reduce the family gap to a larger extent than the gender gap and that wage compressing policies can have opposing effects on the two gaps if they result in high unemployment which hurts high turnover workers such as mothers the most.

Our detailed analysis of the link between labor market institutions and the gender and family gaps confirms these hypotheses. We find that wage 
compressing institutions have a markedly different impact on the family gap and on the gender gap. In particular, we find that while the gender gap decreases with the intensity of wage compressing institutions, these institutions are associated to a bigger family gap, with a particularly strong effect for collective bargaining coverage. The structure of the paper is as follows. Section 2 describes the data we use in this paper. Section 3 describes the analytical framework. Section 4 shows the results. In section 5 we test the robustness of the results. Section 6 concludes.

\section{The Data}

In this study we use two types of data: microdata to estimate the gender and family earnings gap, and data on the intensity of various labor market institutions across countries. The data on labor market institutions is explained in detail in the next section. In relation to the data that we use to estimate the gender and family gaps, we use microdata for thirty five countries from the 1988, 1994 and 2002 annual files of the International Social Survey Programme (ISSP). The International Social Survey Programme (ISSP) is a continuing annual program of cross-national collaboration on surveys covering topics in different areas. Each year, the ISSP administers a common set of basic demographic information questions, such as age, education, gender, income, employment status, marital status, etc. This common set of questions is complemented every year by additional questions on a different topic of social interest. In the years 1988, 1994 and 2002, the ISSP conducted the 'Family and Changing Gender Roles' studies, which in addition to the common set of questions, asked respondents questions related to motherhood, childbearing and job market interruptions around childbirth. 
Table 1

List of countries and years. ISSP data. 'Family and Changing Gender Roles' study.

\begin{tabular}{|c|c|c|c|c|}
\hline Country & Years & Area & Earnings & $\begin{array}{l}\text { Sample Size - all } \\
\text { women* }^{*}\end{array}$ \\
\hline \multirow[t]{2}{*}{ Australia } & 1994,2002 & Liberal & $\begin{array}{l}\text { Annual gross wage and salary } \\
\text { income (1994) }\end{array}$ & 790 \\
\hline & & & Monthly net income (2002) & \\
\hline Austria & 1988, 1994 & Continental & $\begin{array}{l}\text { Monthly net income (1988) } \\
\text { Monthly net earnings (1994) }\end{array}$ & 784 \\
\hline Belgium & 2002 & Continental & Net monthly income & 709 \\
\hline Brazil & 2002 & Other & Monthly earnings & 1,016 \\
\hline Bulgaria & 2002 & Eastern & Monthly net income & 623 \\
\hline Chile & 2002 & Other & Monthly net income & 843 \\
\hline Cyprus & 2002 & Other & Annual income & 506 \\
\hline Czech Republic & 1994, 2002 & Eastern & Monthly net income & 818 \\
\hline Denmark & 2002 & Nordic & Annual gross income & 752 \\
\hline Finland & 2002 & Nordic & Monthly income & 745 \\
\hline France & 2002 & Continental & Monthly earnings & 1,259 \\
\hline Germany (East) & 1988 & Eastern & Monthly net income & 569 \\
\hline Germany (West) & 1988,2002 & Continental & Monthly $n$ et income & 1,092 \\
\hline \multirow[t]{2}{*}{ Hungary } & 1994,2002 & Eastern & Monthly gross earnings (1994) & 815 \\
\hline & & & Monthly income (2002) & \\
\hline Ireland & 1994 & Liberal & Weekly net earnings & 575 \\
\hline \multirow[t]{2}{*}{ Israel } & 1994,2002 & Other & Monthly earnings (1994) & 688 \\
\hline & & & Monthly net income (2002) & \\
\hline Italy & 1988, 1994 & Southern & Monthly net income & 529 \\
\hline Japan & 1994,2002 & Other & Annual gross earnings & 659 \\
\hline Latvia & 2002 & Eastern & Monthly net income & 576 \\
\hline Mexico & 2002 & Other & Earnings & 888 \\
\hline Netherlands & 1988 & Continental & Annual net earnings & 984 \\
\hline New Zealand & 1994,2002 & Liberal & Annual gross income & 593 \\
\hline \multirow[t]{2}{*}{ Norway } & 1994, 2002 & Nordic & Annual gross earnings (1994) & 960 \\
\hline & & & Gross income (2002) & \\
\hline Philippines & 2002 & Other & Monthly income & 600 \\
\hline Poland & 1994, 2002 & Eastern & Monthly net earnings & 797 \\
\hline Portugal & 2002 & Southern & Monthly net income & 649 \\
\hline Russia & 1994,2002 & Eastern & Monthly net earnings & 1,187 \\
\hline Slovak Republic & 2002 & Eastern & Earnings & 589 \\
\hline Slovenia & 1994,2002 & Eastern & Monthly regular income & 574 \\
\hline Spain & 2002 & Southern & Monthly earnings & 1,285 \\
\hline \multirow[t]{2}{*}{ Sweden } & 1994,2002 & Nordic & Monthly gross earnings (1994) & 628 \\
\hline & & & Monthly gross income (2002) & \\
\hline Switzerland & 2002 & Continental & Monthly earnings & 514 \\
\hline Taiwan & 2002 & Other & Earnings & 1,007 \\
\hline United Kingdom & 1988, 1994, 2002 & Liberal & Annual gross earnings & 1,098 \\
\hline United States & 1988, 1994, 2002 & Liberal & Annual gross earnings & 778 \\
\hline
\end{tabular}

* When a country appears more than one year in the data the number in the column is the average sample size across years. 
The advantage of the ISSP data is the large number of countries for which there is information: thirty five in our sample. Its disadvantage is the small size of some country-year samples, although the ISSP questions are asked of a probability-based nation-wide sample of adults. In section 4 we describe the methodology that we use in this study, which we think helps to overcome the potential problems of the small sample sizes.

Table 1 shows the list of countries, the years each country appears in the data and the earnings concept being asked in the questionnaire. The third column also includes our own labeling of each country into six groups. Throughout the paper we present results for each of these groups of countries. As can been in the table, in the ISSP respondents report earnings differently depending on the country. While in some countries respondents report earnings before taxes in others they report earnings after taxes. In our initial models we included a dummy variable indicating whether the earnings concept was gross or net of taxes. This dummy variable was never significant for the estimation of the family or the gender gap. ${ }^{4}$ Also, for some countries, the earnings are top coded. When this was the case, we followed two alternatives: to either drop these observations from the analysis, or to assign to each the lower bound of the income interval. In each case we obtained practically identical results and we present here the results with these observations dropped.

The ISSP data does not give information on the number of weeks worked. However, respondents report the number of hours worked per week, which we used to fit earnings regressions conditional on part-time or full-time employment, where part-time employment is defined as working less than 35 hours per week.

In relation to the human capital variables, we were able to construct years of education for each individual in each country. With respect to labor market experience, we don't have information about years of experience or job tenure. We constructed potential experience combining the information on years of education and age of the individual. Although years of experience and/or job

4. Blau and Kahn (2003) report similar results in their study that also uses the ISSP data for years 1985-94, which suffers from similar variation in the way the earnings concept is reported. 
Table 2

List of countries and information on labor market institutions.

\begin{tabular}{|c|c|c|c|c|c|c|}
\hline Country & $\begin{array}{l}\text { Parental } \\
\text { Leave }\end{array}$ & $\begin{array}{l}\text { Job } \\
\text { Protection }\end{array}$ & $\begin{array}{l}\text { Temporary } \\
\text { Contracts }\end{array}$ & $\begin{array}{l}\text { Trade Union } \\
\text { Coverage }\end{array}$ & $\begin{array}{l}\text { Unemployment } \\
\text { Benefits }\end{array}$ & $\begin{array}{l}\text { Minimum } \\
\text { Wage }\end{array}$ \\
\hline Australia & $x$ & $x$ & $x$ & $X$ & $x$ & $x$ \\
\hline Austria & $x$ & $X$ & $x$ & $x$ & $x$ & $x$ \\
\hline Belgium & $x$ & $x$ & $x$ & $x$ & $x$ & $x$ \\
\hline Brazil & & & & & $x$ & \\
\hline Bulgaria & & & & & $x$ & \\
\hline Chile & & & & & $x$ & \\
\hline \multicolumn{7}{|l|}{ Cyprus } \\
\hline $\begin{array}{l}\text { Czech } \\
\text { Republic }\end{array}$ & $x$ & $x$ & $x$ & $x$ & $x$ & \\
\hline Denmark & $x$ & $x$ & $x$ & $x$ & $x$ & \\
\hline Finland & $x$ & $x$ & $x$ & $x$ & $x$ & \\
\hline France & $x$ & $x$ & $x$ & $x$ & $x$ & $x$ \\
\hline \multicolumn{7}{|l|}{$\begin{array}{l}\text { Germany } \\
\text { (East) }\end{array}$} \\
\hline $\begin{array}{l}\text { Germany } \\
\text { (West) }\end{array}$ & $x$ & $x$ & $x$ & $x$ & $x$ & \\
\hline Hungary & $x$ & $x$ & $x$ & $x$ & $x$ & \\
\hline Ireland & $x$ & $X$ & $x$ & $x$ & $x$ & \\
\hline \multicolumn{7}{|l|}{ Israel } \\
\hline Italy & $x$ & $x$ & $x$ & $x$ & $x$ & \\
\hline Japan & $x$ & $x$ & $x$ & $x$ & $x$ & $x$ \\
\hline \multicolumn{7}{|l|}{ Latvia } \\
\hline Mexico & $x$ & $x$ & $x$ & & $x$ & \\
\hline Netherlands & $x$ & $x$ & $x$ & $x$ & $x$ & $x$ \\
\hline New Zealand & & $x$ & $x$ & $x$ & $x$ & $x$ \\
\hline Norway & $x$ & $x$ & $x$ & $x$ & $x$ & \\
\hline Philippines & & & & & $x$ & \\
\hline Poland & $x$ & $x$ & $x$ & $x$ & $x$ & \\
\hline Portugal & $x$ & $x$ & $x$ & $x$ & $x$ & $x$ \\
\hline Russia & & & & & $x$ & \\
\hline $\begin{array}{l}\text { Slovak } \\
\text { Republic }\end{array}$ & $x$ & $x$ & $x$ & $x$ & $x$ & \\
\hline Slovenia & & & & & $x$ & \\
\hline Spain & $x$ & $x$ & $x$ & $x$ & $x$ & $x$ \\
\hline Sweden & $x$ & $X$ & $x$ & $x$ & $x$ & \\
\hline Switzerland & $x$ & $x$ & $x$ & $x$ & $x$ & \\
\hline Taiwan & & & & & $x$ & \\
\hline $\begin{array}{l}\text { United } \\
\text { Kingdom }\end{array}$ & $x$ & $x$ & $x$ & $x$ & $x$ & $x$ \\
\hline United States & $x$ & $x$ & $x$ & $x$ & $x$ & $x$ \\
\hline $\begin{array}{l}\text { TIME- } \\
\text { VARYING }\end{array}$ & NO & YES & YES & YES & NO & YES \\
\hline
\end{tabular}


tenure are both important determinants of the earnings of mothers and nonmothers, our focus here is on quantifying the earnings gap between mothers and other women, and on relating that gap to various labor market institutions. A different question of course, is to what extent the existing gap is due to a price effect or to a human capital effect, a question that we do not attempt to answer here.

With respect to the labor market institutions, in this study we look at two groups of institutions and construct time-varying measures of each one for as many countries as possible. Table 2 shows for each country, whether there is information available on each labor market institution and whether the variable is time-varying.

First, we look at institutions that potentially help mothers continue with the same job after a child is born. In this group, we construct measures of the following three policies: parental leave, impediments to the firing of workers and restrictions to the use of temporary contracts by firms. Information about these policies comes from the O.E.C.D. Employment Outlook (2001) in the case of parental leave and the O.E.C.D. Employment Outlook (2004) in the case of job protection regulations. The Data Appendix shows detailed information of each one of these policies for each country in our sample.

We use two measures of parental leave policies, the maximum duration of parental leave (in weeks) and the earnings replacement rate while on leave. For the protection of jobs, we use an index of the overall strictness of protection of regular contracts and an index of the restrictions on the use of temporary contracts. The first index combines information on various aspects of the protection of workers under regular contracts against dismissal (indefinite contracts), such as the period of advance notice, administrative obstacles to the dismissal of workers, the level of severance payments and cases considered unfair dismissal (usually subject to higher severance payments). The index on the restrictions to the use of temporary contracts or fixed-term contracts usually subject to low or no protection against termination - measures to what 
extent and in which cases temporary contracts are valid according to the law. ${ }^{5}$ In the case of job protection measures, the information is time varying, with data given for the eighties, nineties and two thousands, and we assign the value for the eighties to observations in the ISSP dataset for 1988, the value for the nineties to observations for 1994 and the value for two thousands to observations for 2002 .

Theoretically, the impact of parental leave on the family gap is ambiguous (Waldfogel, 1998). On the one hand, parental policies help mothers continue with the same employer/job after childbirth, allowing women with children to accumulate job market experience and/or maintain firm specific human capital. On the other hand, generous parental leave might induce mothers to stop working for longer periods than otherwise, with the corresponding bigger loss of human capital.

The impact of job protection regulations on the family gap is also ambiguous. Job protection regulations help mothers continue with the same employer after childbirth and since they benefit mothers as long as they continue working, they discourage job interruptions. However, job protection regulations, if too strict, can lead to unemployment because in the presence of strict firing procedures firms become too cautious in the hiring process, and in the presence of unemployment, mothers that decide either voluntarily or involuntarily to interrupt their career to take care of children might go through a longer job interruption than otherwise. Furthermore, in dual labor markets workers with regular contracts benefit from strict firing restrictions while workers under temporary contracts get low or no protection against dismissal (Dolado et al, 2005). The restrictions to the use of temporary contracts are important here, because in some countries firms easily get around the strict regulation of regular contracts by employing a worker under a series of consecutive temporary contracts. When there is the possibility of using temporary contracts, job tenure is important to gain access to a protected job, because the law usually establishes

5. The O.E.C.D. Employment Outlook (2004) provides information on other aspects of the regulation of temporary contracts such as the maximum number of contracts that can be signed consecutively by the same firm and workers. The effect of these on job transitions is less clear than that of the index we use here and we found these other aspects to be non-significant when we included them in our models. 
a limited duration and limited number of consecutive fixed-term contracts. In this context, it is possible that mothers, with lower average tenure than nonmothers, disproportionately concentrate in the secondary market, under temporary hence unprotected contracts.

The second type of labor market institutions we consider is traditionally associated with wage compression, that is, with a lower wage gap between various groups of workers, such as male and female (Blau and Kahn, 2003). In this group we gather information about the following institutions: collective bargaining coverage, unemployment benefits, and the minimum wage. We get the information on the minimum wage from the O.E.C.D. minimum wage database, which reports the ratio of the minimum wage to the average wage for 1986 and 2000. We assign the 1986 value to observations in the ISSP for 1988, and the 2000 value to the observations for 1994 and 2002. We get the information on collective bargaining coverage from the O.E.C.D. Employment Outlook (2004), which reports time varying measures of union coverage, for the eighties, the nineties and the two thousands. Having time varying information is important here because of the changes in many O.E.C.D. countries during the eighties and nineties in the direction of lowering the power of unions (Nickell 1997, Siebert 1997). Information on the level of unemployment benefits was taken from Botero et al., (2004). This is a one-time index of the generosity of unemployment benefits, combining information on the replacement rate and the duration of unemployment benefits, covering all except one of the thirty five countries in our sample.

The effect of wage compressing institutions on the family gap is also ambiguous. The bargaining of wages by unions and the minimum wage may raise the relative wage of mothers, provided that women with children are at the bottom of the wage distribution. Unemployment benefits may help mothers who stopped working and want to return to the labor market to get a higher wage than otherwise by allowing them to search longer and find a better match. However, these institutions may lead to unemployment causing mothers who decide to transition out of employment to suffer a long career break.

Table 3 shows the correlation coefficients between these various labor market institutions. On average countries with stricter protection of regular jobs also 
have more generous parental leave policies, more generous unemployment benefits and more powerful unions. Furthermore, stricter protection of regular contracts is on average coupled with fewer restrictions on the use of temporary contracts by firms, a clear indication of dual markets with respect to job protection. As we will se next, this positive correlation between policies is important to understand the weak association between the gender and the family gaps across countries.

Table 3

Correlation coefficients. Labor market institutions

\begin{tabular}{llllll}
\hline & LEAVE & PROTECTREG & RESTRICTEMP & COVERAGE & UBENEFITS \\
\hline LEAVE & 1 & & & & \\
PROTECTREG & 0.4627 & 1 & & & \\
RESTRICTTEMP & -0.1653 & -0.3152 & 1 & 1 & \\
COVERAGE & 0.3545 & 0.4197 & -0.409 & 1 & \\
UBENEFITS & 0.6727 & 0.3018 & -0.0996 & 0.2837 & 1 \\
\hline
\end{tabular}

Notes: LEAVE indicates the duration of the parental leave period; PROTECTREG indicates the strictness of regulations governing the firing of workers with regular contracts. RESTRICTEMP indicates the strictness of restrictions on the use of temporary contracts by firms. COVERAGE indicates trade union coverage.

UBENEFITS indicates the generosity of social benefits to the unemployed.

\section{Analytical Framework}

Our empirical analysis consists of two steps. In the first step we estimate the family gap in each of 35 countries using the microdata available. In the second step, we estimate reduced form specifications with the family gap as the endogenous variable and the various types of labor market institutions as explanatory variables.

With respect to the estimation of the family gap, we follow the methodology of Blau and Kahn (2003) which uses the same dataset as ours to analyze the gender gap in twenty two countries. ${ }^{6}$ We start by using individual data to estimate log earnings equations separately for mothers and non-mothers for each country $\mathrm{j}$ and year $\mathrm{t}$ :

$$
\begin{aligned}
& \ln \operatorname{EARN}_{i j t}=b_{0 j t}+b_{1 j t} \operatorname{PART}_{i j t}+b_{2 j t} \operatorname{HRPART}_{i j t}+b_{3 j t} \operatorname{HRFULL}_{i j t} \\
& +X_{i j t} \cdot B_{j t}+\operatorname{KIDS}_{i j t} \cdot K_{j t}+e_{i j t}
\end{aligned}
$$

6. For a more detailed description of this methodology see Blau and Kahn (2003), pp. 115-123. 
where $\mathrm{i}$ indexes individuals; lnEARN is the natural log of earnings; PART is a dummy variable for part-time employment, defined as working less than thirty five hours per week; HRPART and HRFULL are interactions of weekly work hours with part-time and full-time status; $\mathrm{X}$ is a vector of explanatory variables, including the usual human capital variables of education, potential experience and the square of potential experience; KIDS is a vector of four dummy variables included in the earnings equations of mothers only, indicating whether the mother has one child, two children, three children or four or more children. Unfortunately, the ISSP data does not give information on the number of children so we had to estimate this variable combining information on the marital status of women and the number of members in the household. Since we identify children as long as they live with their mother in the same household, we restricted our sample to women younger than 50 years of age. Having estimated (1), we compute the family gap in pay in each country and year as follows:

FAMILYGAP $P_{j t}=$

$\left(\begin{array}{l}b_{0 N M j t}+b_{1 N M j i t} P A R T_{N M U S t}+b_{2 N M j i t} H_{R P A R T_{N M U S t}}+b_{3 N M j i t} H_{R F U L L_{N M U S t}} \\ +X_{\text {NMUSt }} \cdot B_{\text {NMjit }}\end{array}\right)$

$-\left(\begin{array}{l}b_{0 M j t}+b_{1 M j i} P A R T_{M U S t}+b_{2 M j i} H R P A R T_{M U S t}+b_{3 M j t} H R F U L L_{M U S t} \\ +X_{M U S t} \cdot B_{M j t}+K I D S_{M U S t} \cdot K_{M j t}\end{array}\right)$

where NM refers to non-mothers, US refers to the US values and M refers to mothers. According to equation (2), FAMILYGAP is an estimate of the gap in earnings between mothers and non-mothers in each country and year on the assumption that the group of mothers and non-mothers in each country-year microdata file have the same average levels of measured characteristics (i.e., PART, HRPART, HRFULL, $X$ and KIDS variables) as the group of U.S. mothers and non-mothers for that year. Equation (2) provides a simulated family gap that removes the effect of differences in observable characteristics across countries. However, labor market institutions can still have an effect on the family gap in at least two ways. First, labor market institutions can be important for the different returns to the same characteristics for mothers and non-mothers. Second, since differences in measured characteristics between mothers and nonmothers remain (at the U.S. level) labor market institutions that affect the price of these characteristics will play a role in determining the family gap. 
In relation to the human capital effect component of the family gap, equation (2) allows for institutions to play a role with respect to job market experience. The reason is that the $\mathrm{X}$ vector includes potential experience (age - education years six), instead of actual experience. We then remove cross country differences in potential experience, but not in actual experience. Suppose for example that in country $\mathrm{j}$ job protection is weak and because of this mothers lose their job frequently and spend a lot of time out of employment when children are born. In equation (2) the coefficient of potential experience would be relatively low, compared to another country. In general, when the coefficient of potential experience is low this could mean either that returns to experience are low or that mothers accumulate less experience. This will be true in general for all variables potentially correlated with actual experience, such as the number of kids and possibly part-time status. With respect to the other variables in $\mathrm{X}$ besides potential experience (education, part-time status and the number of kids), equation (2) does not allow for cross country differences in these variables to play a role. When we estimated the family gap allowing for cross country differences in these variables to play a role we obtained very similar results, although noisier in general. We think that removing international differences in observable characteristics (with the exception of actual experience) is an advantage of our methodology because in many cases the size of the countryyear samples are too small for the distribution of X's in our data to be representative. Besides, our hypothesis is that the most important effect of labor market institutions on human capital variables is their impact on the accumulation of job market experience.

With respect to the reduced form specifications, our sample consists of 54 country-year observations. Following Blau and Kahn (2003), we start by running regressions of the family gap on two measures of male wage dispersion. The hypothesis here is that observed male wage inequality is influenced by both heterogeneity of productivity characteristics and by the returns to these characteristics, being the effect of labor market institutions more important in the latter. The two measures of male wage dispersion remove then the effects of international differences in measured heterogeneity. First, for each country and year we take the U.S. sample of men for that year and compute a predicted log wage for each U.S. male using the coefficients from the wage regression for country $\mathrm{j}$ and year $\mathrm{t}$. We then compute two measures of wage dispersion: the 
standard deviation of low wages (SD) and the standard deviation of the residuals (SDRES). These two measures give us an idea of the degree of wage inequality in country $j$ at year $t$ that results from the returns to measured and unmeasured characteristics in that country and year:

$$
\text { FAMILYGAP }_{j t}=b_{0}+S D_{j t} \cdot b_{1}+\text { SDRES }_{j t} \cdot b_{2}+Y E A R_{j t} \cdot Y+e_{j t}
$$

where YEAR is a vector of year dummies and e is the error term. We then turn to the reduced form specifications that include the various labor market institutions we are interested in. All of our models include year dummies and take the following specification:

$$
\text { FAMILYGAP }_{j t}=b_{0}+I N S_{j t} \cdot B I+Y E A R_{j t} \cdot Y+e_{j t}
$$

where INS is a vector of explanatory variables indicating the level of the various labor market institutions; YEAR is a vector of year dummies and e is the error term.

\section{Results}

Figure 1 offers a first look at the family gap across the thirty five countries in our sample. In the figure, we plot the family gap computed using the methodology described in Section 3 (FAMILYGAP) against the family gap in the raw data, i.e., allowing the set of observable characteristics to vary across countries and groups of women.

From the figure we can see that there is a positive correlation between the two measures of the family gap (the correlation coefficient is .52). The negative values for some countries and years disappear when we impose the US level of observable characteristics of mothers and non-mothers to the rest of countries, an indication that some of these negative values were driven by the different characteristics of mothers and non-mothers in those countries rather than the returns to those characteristics. As we argued before, we think that this is an advantage of our methodology, because it is hard to draw conclusions from the 
different distributions of characteristics across countries, considering the small size of some of the samples in the ISSP data set. ${ }^{7}$

\section{Figure 1}

Family gap. Fitted values versus raw data. ISSP data.

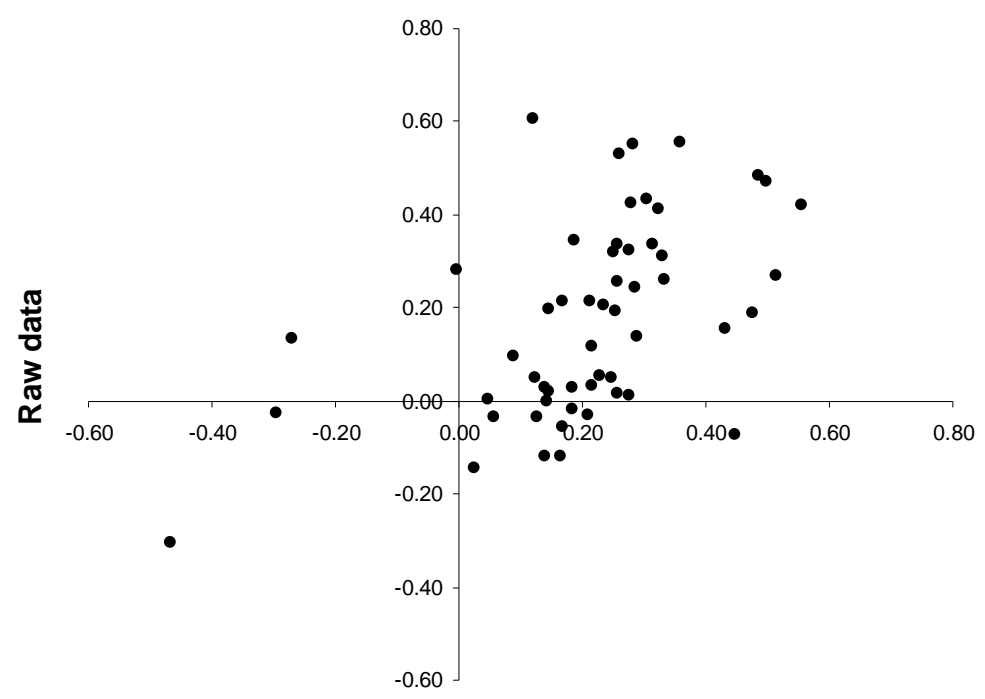

Fitted values (FAMIL YGAP)

Table 4

Average family and gender gaps, male wage compression

\begin{tabular}{lcccc}
\hline & FAMILYGAP & GENDERGAP & SD & SDRES \\
\hline Southern Europe & .3560 & .2864 & .3136 & .4792 \\
Liberal & .3196 & .3971 & .4370 & .4727 \\
Continental & .2432 & .3091 & .3548 & .4664 \\
Nordic & .2088 & .2602 & .3245 & .4810 \\
Other & .1065 & .4175 & .3792 & .4866 \\
Eastern & .1404 & .3080 & .3261 & .4857
\end{tabular}

Note: $\quad$ FAMILYGAP and GENDERGAP are respectively the predicted family gap and gender gap evaluated at U.S. values for mother and non-mother, men and women characteristics; SD is the standard deviation of predicted log wages applying each country's male wage equation to U.S. men; SDRES is the standard deviation of each country's male log wage residuals calculated from its male wage equation.

Table 4 shows the average family gap and the two measures of wage dispersion for the five groups of countries in our sample. For comparison purposes, the

7. The three observations with negative numbers in FAMILYGAP correspond to Philippines 2002, Czech Republic 2002 and Taiwan 2002. When we dropped these observations the results we obtained were practically identical, although the fit of the various models was slightly lower. 
table also shows the earnings gap between men and women, the gender gap, calculated with identical methodology as the family gap. The table indicates that Southern European countries have the largest family gap, even though the gender gap is relatively small there. More generally, there is only a weak correlation between the family and the gender gaps (the correlation coefficient between the two is only .1017), which suggests that the impact of the various labor market policies in each gap might be quite different.

Table 5

OLS Regression results - Male wage compression

\begin{tabular}{lllll|llll}
\hline \multicolumn{4}{c}{ Dependent Variable $=$ FAMILYGAP } & \multicolumn{3}{c}{ Dependent Variable = GENDERGAP } \\
& Coeff. & t-stat (SE) & Coeff. & $\begin{array}{l}\text { t-stat } \\
\text { (SE) }\end{array}$ & Coeff. & $\begin{array}{l}\text { t-stat } \\
\text { (SE) }\end{array}$ & Coeff. & t-stat (SE) \\
\hline SD & .2986 & 1.14 & .3242 & 1.21 & .3427 & 1.80 & .3696 & 1.91 \\
& & $(.2622)$ & & $(.2683)$ & & $(.1901)$ & & $(.1939)$ \\
SDRES & & & 1.1529 & .54 & & & 1.2104 & .79 \\
& & & & $(2.1321)$ & & & & $(1.5408)$ \\
Year & YES & & YES & & YES & & YES & \\
dummies & & & & & & & & \\
Sample size & 54 & & 54 & & 54 & & 54 & \\
R2 & .12 & & .12 & & .15 & & .16 & \\
\hline
\end{tabular}

Note: $\quad$ SD is the standard deviation of predicted log wages applying each country's male wage equation to US men. SDRES is the standard deviation of each country's male log wage residuals calculated from its male wage equations.

Table 5 shows the results for the OLS estimation of equation (3). The table indicates that higher wage dispersion - higher returns to observable and unobservable characteristics - is associated to a higher gender gap but only weakly associated to a higher family gap. Residual inequality is not statistically significant for both gaps and the standard deviation of wages is statistically significant at the $10 \%$ level in the case of the gender gap and at the $25 \%$ level in the case of the family gap. One possible explanation of the results in Table 5 is that labor market institutions are more effective at setting a wage floor in the case of women in general than in the case of mothers in particular. In dual labor markets high-tenure and high-experience workers benefit from social policies disproportionately compared to low-tenure and low-experience workers. It has been argued that unions fight harder for insiders than outsiders. Also, in some countries, Spain being an example, the severance package grows with tenure and both the duration and replacement rate of unemployment benefits grows with 
job market experience, giving high-tenure and high-experience workers more power to reject wage cuts or even bargain for a wage increase.

Another explanation is that mothers accumulate less human capital in the presence of labor market institutions that compress wages, something that could happen if wage compressing institutions lead to unemployment and this causes mothers who transition out of the labor market to go through long unemployment spells.

In Tables 6 to 8 we show the results of estimating various reduced form specifications where, instead of the male wage dispersion measures we include proxies for labor market institutions which can affect wage compression overall and the family gap in particular.

Table 6 shows the results for the group of what we call tenure enhancing policies: the duration of parental leave (LEAVEWKS), the replacement rate of earnings while in parental leave (LVREP), the protection of regular jobs (PROTREG) and restrictions to the use of temporary contracts by firms (RESTRICTEMP). Across all specifications, each of these policies is associated to a lower family gap, i.e., the more generous parental leave, the stricter the restrictions to job termination and the stricter the restrictions on the use of temporary contracts, the lower the family gap. The significance of parental leave duration is greater than that of its replacement rate and when parental leave is combined with job protection the fit of the model improves although the impact of parental leave falls and becomes insignificant. The effect of job protection and of restrictions to the use of temporary contracts is large and highly significant in all specifications. For example, using the coefficients in the complete specification, if the group of Liberal countries had the same level of job protection of regular jobs as the group of Nordic countries, the family gap would fall in the former by $21.9 \%$ or .07 log points. Also, if Southern European countries had the same duration of parental leave as Nordic countries, the family gap would fall in the former by $.048 \log$ points or $13.4 \%$. 
Table 6

Results for parental leave and job protection. OLS regressions

\begin{tabular}{|c|c|c|c|c|c|c|c|c|c|c|c|c|c|c|c|c|c|c|}
\hline & \multicolumn{10}{|c|}{ FAMILY GAP } & \multicolumn{8}{|c|}{ GENDER GAP } \\
\hline & Coeff & t. (SE) & Coeff & t. (SE) & Coeff & t. (SE) & Coeff & t. (SE) & Coeff & t. (SE) & Coeff & t. (SE) & Coeff & t. (SE) & Coeff & t. (SE) & Coeff & t. (SE) \\
\hline LVWEEKS & -.0030 & $\begin{array}{l}-1.87 \\
(.0016)\end{array}$ & -.0025 & $\begin{array}{l}-1.37 \\
(.0018)\end{array}$ & & & & & -.0017 & $\begin{array}{l}-.98 \\
(.0017)\end{array}$ & -.0027 & $\begin{array}{l}-1.65 \\
(.0016)\end{array}$ & -.0023 & $\begin{array}{l}-1.25 \\
(.0018)\end{array}$ & & & & \\
\hline LVREP & & & -.0005 & $\begin{array}{l}-.64 \\
(.0008)\end{array}$ & & & & & & & & & -.0004 & $\begin{array}{l}-.53 \\
(.0008)\end{array}$ & & & & \\
\hline PROTREG & & & & & -.0578 & $\begin{array}{l}-2.27 \\
(.0255)\end{array}$ & -.0679 & $\begin{array}{l}-2.57 \\
(.0264)\end{array}$ & -.0558 & $\begin{array}{l}-1.85 \\
(.0301)\end{array}$ & & & & & -.0165 & $\begin{array}{l}-.62 \\
(.0266)\end{array}$ & -.0068 & $\begin{array}{l}-.25 \\
(.0276)\end{array}$ \\
\hline RESTRICTEMP & & & & & & & -.0173 & $\begin{array}{l}-1.32 \\
(.0131)\end{array}$ & -.0166 & $\begin{array}{l}-1.23 \\
(.0134)\end{array}$ & & & & & & & .0166 & $\begin{array}{l}1.21 \\
(.0137)\end{array}$ \\
\hline Year dummies & YES & YES & YES & YES & YES & YES & YES & YES & YES & YES & YES & YES & YES & YES & YES & YES & YES & YES \\
\hline Sample size & 38 & & 37 & & 40 & & 40 & & 38 & & 38 & & 37 & & 40 & & 40 & \\
\hline $\mathrm{R} 2$ & .15 & & .17 & & .17 & & .21 & & .25 & & .16 & & .17 & & .11 & & .14 & \\
\hline
\end{tabular}

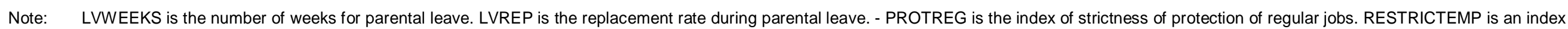
of how difficult is for firms to hire workers under temporary contracts (the higher the index the more difficult this is). 
Overall, these results indicate that policies that help mothers continue with the same employer/job after childbirth reduce the wage penalty associated to motherhood. It should be recalled that the effect of parental leave on the family gap is theoretically ambiguous, since generous parental leave might induce mothers to stay out of employment for longer periods of time than otherwise, with the corresponding loss of experience. The results in Table 6 confirm those obtained by previous studies using British and U.S. data (Waldfogel 1995, Waldfogel 1998), and suggest that the net effect of parental leave on human capital is a positive one.

The comparison between the family and the gender gap in Table 6 indicates that while parental leave is associated to a lower gender gap, the protection of jobs bears no relation with it. These results are intuitive. Whereas women tend to benefit disproportionately, compared to men, from parental leave policies, instead, job protection regulations and restrictions on the use of temporary contracts are important for both men and women.

We turn now to the analysis of wage compressing institutions. Table 7 shows the results for collective bargaining coverage. We look at two measures of collective bargaining coverage: the percentage of the work force directly or indirectly affected by unions' agreements (COVERAGE) ${ }^{8}$ and the ranking of countries in relation to trade union coverage (RANK). The reason for including this second measure is that the O.E.C.D. reported measure of trade union coverage is top coded for some countries. The RANK variable however, is insignificant and we dropped it from all except the initial specification. Looking at the impact of trade union coverage on the family gap, the results in the table indicate that more powerful unions are associated to a bigger family gap, since the sign of the coefficient is positive across all specifications.

8. This measure is normally bigger than trade union density, which measures the percentage of workers directly affiliated to unions or directly represented by them. 
Table 7

Results for collective bargaining coverage. OLS regression

\begin{tabular}{|c|c|c|c|c|c|c|c|c|c|c|c|c|}
\hline & \multicolumn{8}{|c|}{ FAMILY GAP } & \multicolumn{4}{|c|}{ GENDER GAP } \\
\hline & Coeff & t. (SE) & Coeff & t. (SE) & Coeff & t. (SE) & Coeff & t. (SE) & Coeff & t. (SE) & Coeff & t. (SE) \\
\hline COVERAGE & .0004 & $\begin{array}{l}.45 \\
(.0010)\end{array}$ & .0011 & $\begin{array}{l}.83 \\
(.0013)\end{array}$ & .0010 & $\begin{array}{l}1.01 \\
(.0010)\end{array}$ & .0016 & $\begin{array}{l}1.49 \\
(.0011)\end{array}$ & -.0030 & $\begin{array}{l}-3.67 \\
(.0008)\end{array}$ & -.0030 & $\begin{array}{l}-3.13 \\
(.0009)\end{array}$ \\
\hline RANK & & & -.1137 & $\begin{array}{l}-.75 \\
(.1512)\end{array}$ & & & & & & & & \\
\hline PROTREG & & & & & -.0838 & $\begin{array}{l}-2.83 \\
(.0296)\end{array}$ & -.0684 & $\begin{array}{l}-2.17 \\
(.0314)\end{array}$ & & & & \\
\hline RESTRICTEMP & & & & & -.0291 & $\begin{array}{l}-1.82 \\
(.0160)\end{array}$ & -.0262 & $\begin{array}{l}-1.62 \\
(.0161)\end{array}$ & & & & \\
\hline LVWEEKS & & & & & & & -.0028 & $\begin{array}{l}-1.55 \\
(.0018)\end{array}$ & & & -.0009 & $\begin{array}{l}-.56 \\
(.0016)\end{array}$ \\
\hline Year dummies & YES & YES & YES & YES & YES & YES & YES & YES & YES & YES & YES & YES \\
\hline Sample size & 34 & & 34 & & 34 & & 32 & & 34 & & 32 & \\
\hline R2 & .05 & & .07 & & .29 & & .37 & & .34 & & .36 & \\
\hline
\end{tabular}

Note: LVWEEKS is the number of weeks for parental leave. LVREP is the replacement rate during parental leave. - PROTREG is the index of strictness of protection of regular jobs. RESTRICTEMP is an index of how difficult is for firms to hire workers under temporary contracts (the higher the index the more difficult this is). COVERAGE is the percentage of employees affected directly or indirectly by trade union arrangements. RANK is the ranking of countries from the lowest level of trade union coverage to the highest. 
Furthermore, the magnitude and the significance of the coefficient grow as we include other covariates such as parental leave policies and job protection regulations. The reason for this is that in our sample of countries there exists a positive correlation between trade union coverage, parental leave and job protection regulations (see Table 3), and the effect of trade union coverage on the family gap is opposed to that of parental leave and job protection. In the last specification, not only the size and the significance of the trade union coefficient grows, but also that of the parental leave and job protection coefficients, compared to Table 6. Furthermore, combining these four policies in the same specification improves the fit of the model, which now explains $37 \%$ of the variation in the family gap across time and across countries. ${ }^{9}$ With respect to the size of the COVERAGE coefficient, the results in the table indicate that if, for example, Southern European countries had the same level of trade union coverage as the group of Liberal countries then the family gap would fall in the former by $.057 \log$ points or $16 \%$.

With respect to the effect of trade union coverage on the gender gap, Table 7 shows an important contrast, since trade union coverage is associated to a bigger family gap but to a lower gender gap. The negative effect of trade union coverage on the gender gap is very strong in magnitude and significance, even when we control for parental leave, confirming the results of previous studies (Blau and Kahn 2003). This result confirms our previous intuition that unions fight harder for the job market prospects of men and women than for mothers in particular. If mothers have a weaker attachment to the labor market due to their relatively high turnover rates (Anderson et al. 2003, Data \& Smith 2002, Phipps et al. 2001, Klerman \& Leibowitz 1994), and if unions protect insiders more than outsiders (Lindbeck \& Snower 2001), then unions will have a negligible effect on the family gap but not on the gender gap. However, the fact that the sign of the coefficient in the case of the family gap is positive and significant suggests that unions have an additional negative impact on the family gap. It is possible that unions, while raising the relative wage of those at the bottom of the

9. It should be noted that the number of observations changes across the different specifications. This is due to the fact that we have information on a specific covariate for some countries but not for others. We ran the same regressions limiting our sample to the set of countries for which information on all covariates exists, and the results we obtained were practically identical to the ones shown in the tables. 
wage distribution, women in general, also lead to unemployment which hits particularly strong those with a weaker attachment to the labor market, such as mothers. The fact that female unemployment rates are positively correlated to both trade union coverage (the correlation coefficient is .59 in our sample) and to the size of the family gap, supports this hypothesis. The results in Table 7 are also important to understand the apparently weak association between the family and the gender gaps across countries, something that is not surprising considering that labor market institutions have a different impact on the two gaps and that there is variation of labor market institutions across countries.

Table 8 shows the results for the other two wage compressing institutions: unemployment benefits and the minimum wage. As with the case of collective bargaining coverage, unemployment benefits are associated to a bigger family gap. In all specifications the coefficient is bigger than its standard error and in two of the three specifications is significant at the 5\% level. The magnitude and significance of the coefficient grows as other covariates are included in the model (also because of the positive correlation between institutions and their different effect on the family gap). As for the magnitude of the coefficient, if Nordic countries had the lower level of unemployment benefits of the group of Liberal countries, the family gap would decrease in the former by .10 log points or $49.9 \%$. Adding the unemployment benefits variable to the model improves its fit, explaining now $41 \%$ of the variation of the family gap across time and countries. As in the case of collective bargaining coverage, an intuitive explanation of this result is that while unemployment benefits may raise the relative wage of mothers allowing them to find a better match, they may also encourage mothers to stay out of the labor market longer than otherwise, with the corresponding loss of job market experience. We have to recall here that the correlation coefficient between the generosity of unemployment benefits and the female unemployment rate in our sample is .14. The results for the minimum wage indicate that this variable is not related to the family gap, although we should note that we were able to construct this variable for only ten of the thirty five countries in our sample. In relation to the effect of unemployment benefits and the minimum wage on the gender gap, Table 8 indicates that the minimum wage has a strongly significant and negative impact on the gender gap and that the level of unemployment benefits is not significantly related to the gender gap. 
Table 8

Results for unemployment benefits and the minimum wage. OLS regression

\begin{tabular}{|c|c|c|c|c|c|c|c|c|c|c|c|c|c|c|c|c|}
\hline & \multicolumn{8}{|c|}{ FAMILY GAP } & \multicolumn{8}{|c|}{ GENDER GAP } \\
\hline & Coeff & t. (SE) & Coeff & t. (SE) & Coeff & t. (SE) & Coeff & t. (SE) & Coeff & t. (SE) & Coeff & t. (SE) & Coeff & t. (SE) & Coeff & t. (SE) \\
\hline UBENEFITS & .3933 & $\begin{array}{l}2.96 \\
(.1326)\end{array}$ & .4794 & $\begin{array}{l}2.67 \\
(.1795)\end{array}$ & .5898 & $\begin{array}{l}1.23 \\
(.4777)\end{array}$ & & & -.0697 & $\begin{array}{l}-.64 \\
(.1086)\end{array}$ & .2508 & $\begin{array}{l}.91 \\
(.2748)\end{array}$ & .5512 & $\begin{array}{l}1.24 \\
(.4455)\end{array}$ & & \\
\hline MINWAGE & & & & & & & -.0511 & $\begin{array}{l}-.14 \\
(.3537)\end{array}$ & & & & & & & -.9942 & $\begin{array}{l}-2.67 \\
(.3725)\end{array}$ \\
\hline LVWEEKS & & & -.0038 & $\begin{array}{l}-2.13 \\
(.0018)\end{array}$ & -.0045 & $\begin{array}{l}-1.99 \\
(.0022)\end{array}$ & & & & & & & -.0024 & $\begin{array}{l}-1.20 \\
(.0020)\end{array}$ & & \\
\hline RESTRICTEMP & & & -.0312 & $\begin{array}{l}-2.32 \\
(.0135)\end{array}$ & -.0258 & $\begin{array}{l}-1.61 \\
(.0160)\end{array}$ & & & & & & & & & & \\
\hline COVERAGE & & & & & .0013 & $\begin{array}{l}1.20 \\
(.0011)\end{array}$ & & & & & -.0034 & $\begin{array}{l}-3.71 \\
(.0009)\end{array}$ & -.0032 & $\begin{array}{l}-3.35 \\
(.0009)\end{array}$ & & \\
\hline
\end{tabular}

Note: LVWEEKS is the number of weeks for parental leave. PROTREG is the index of strictness of protection of regular jobs. RESTRICTEMP is an index of how difficult is for firms to hire workers under temporary contracts (the higher the index the more difficult this is). UBENEFITS is an index indicating the generosity of unemploymen benefits. MINWAGE is the ratio of the minimum wage to the average wage. COVERAGE is the percentage of employees affected directly or indirectly by trade union arrangements. 
Overall, the results in tables 6-8 indicate that policies that help mothers continue with the same employer/job after childbirth reduce the family gap, whereas policies aimed at raising the relative wage of mothers increase the family gap. As mentioned before, one possible explanation for this is that wage compressing policies lead to rigid labor markets with high unemployment rates, which increases the length of spells out of employment by mothers around childbirth. Unfortunately, the ISSP data does not give information on the duration of spells out of employment around childbirth, so we cannot directly test this hypothesis. However, there is some indirect evidence that tends to support it. This evidence is shown in Table 9 and in Table 10. Table 9 displays the correlation coefficients across countries between the level of trade union coverage, unemployment benefits, the probability of a job interruption around childbirth and the percentage of women under part-time employment. In the ISSP data, approximately forty percent of mothers answered to the following question: "Did you stop working right after your child was born and during pre-school period?" For these mothers there is also information as to whether they were or not working before childbirth. Combining these two questions we calculated the probability that a mother interrupted her career because of a child spell (JOBINTERRUPT).

\section{Table 9}

Job interruptions, COVERAGE, UBENEFITS, Part-time employment. Correlation coefficients. ISSP data and Institutions data

\begin{tabular}{lccccc}
\hline & JOBINTERRUPT & PART-TIME & UBENEFITS & COVERAGE & URATE-FEMALE \\
\hline JOBINTERRUPT & 1.0000 & & & & \\
PART-TIME & .8016 & 1.0000 & & & \\
UBENEFITS & -.5832 & -.2474 & 1.0000 & & \\
COVERAGE & -.5025 & -.3377 & .5679 & 1.0000 & \\
URATE- & -.4092 & -.4789 & .1391 & .5949 & 1.0000 \\
FEMALE & & & & & \\
\hline
\end{tabular}

Table 9 shows that in countries with a higher level of trade union coverage and more generous unemployment benefits, women face higher unemployment rates, mothers tend to interrupt their careers less frequently and are rarely employed in part-time jobs. This is clearly consistent with a picture of rigid, 'sclerotic', labor markets in which mothers who transition out of employment either voluntarily or involuntarily because of a child spell may suffer a relatively long period of 
joblessness. ${ }^{10}$ In Table 10 we break the family gap in equation (2) in two components. The first component is a proxy for the price effect associated to motherhood. We construct this price effect by removing from the family gap the impact of variables which we think are correlated with the job market experience and the tenure of mothers and non-mothers, i.e., potential experience (POTEXP), part-time status (PART), job interruption controls (JOBINTERRUPT) and the number of kids (KIDS). The price effect component is then, PRICEFFECT $_{j t}=\left(b_{0 N M j i t}-b_{0 M j t}\right)+\left(B_{E D N M j t}-B_{E D M j i t}\right) \cdot e d u c_{U S t}$

where the coefficients are estimated as in equation (1). The price effect is then the sum of two terms. The second term measures the difference in the returns to education between mothers and non-mothers $\left(B_{E D N M j i}-B_{E D M j i}\right)$. Note that in this second term, we set the level of education to be the same for mothers and nonmothers and across countries, at the US level. This is then, a pure price effect due to a different price of education for mothers compared to non-mothers. The first term is the difference in the constant terms for mothers and non-mothers and is supposed to measure the extent the returns to unobserved characteristics are also different between mothers and non-mothers. The human capital effect is simply the difference between the family gap in equation (2) and the price effect:

HCEFFECT $_{j t}=$ FAMILYGAP $_{j t}-$ PRICEFFECT $_{j t}$

Table 10

Price effect versus human capital effect. OLS regression

\begin{tabular}{|c|c|c|c|c|}
\hline & \multicolumn{2}{|c|}{ PRICEFFECT } & \multicolumn{2}{|c|}{ HCEFFECT } \\
\hline & Coeff & $\mathrm{t}$ & Coeff & $\mathrm{t}$ \\
\hline UBENEFITS & -3.7061 & -1.02 & 3.7255 & 1.03 \\
\hline COVERAGE & -.0130 & -1.33 & .0154 & 1.58 \\
\hline PROTREG & .1032 & .45 & -.1756 & -.77 \\
\hline RESTRICTEMP & -.0295 & -.27 & -.0031 & -.03 \\
\hline LVWEEKS & .0246 & 1.50 & -.0266 & -1.63 \\
\hline $\mathrm{R} 2$ & \multicolumn{2}{|c|}{.23} & \multicolumn{2}{|c|}{.29} \\
\hline
\end{tabular}

The results shown in Table 10 should be taken with caution. Given that in the ISSP data we cannot measure job market tenure, it is possible that variables

10. Del Boca et al (2003) and Adserà (2002) argue that in such labor markets women delay their fertility decisions until they have secured an indefinite contract that protects them against the possibility of being laid off because of a child spell. 
included in the PRICEFFECT component capture to some extent the human capital effect due to motherhood, and vice versa. Despite the data limitations we face, the results are broadly consistent with our previous intuition. In the case of the wage compressing institutions, the coefficients are always bigger than its standard errors for both the price and the human capital effects and have a negative sign in the case of the price effect but a positive one in the case of the human capital effect. In other words, according to the results in the table, wage compressing institutions reduce the gap between mothers and non-mothers with respect to the returns on a given set of skills, however, these institutions cause mothers to lose job market experience relative to non-mothers, which increases the family gap. In the case of the tenure enhancing institutions, as expected, all these institutions are associated to a lower human capital effect, although only the parental leave variable remains significant. With respect to this last variable, the table also indicates that parental leave is associated to higher price effect. 
Table 11

Accounting for the difference in the family gap

Log points difference with the average of all countries due to:

\begin{tabular}{|c|c|c|c|c|c|c|c|c|c|}
\hline Region & Family Gap & $\begin{array}{l}\text { Parental } \\
\text { Leave }\end{array}$ & $\begin{array}{l}\text { Job } \\
\text { Protection }\end{array}$ & $\begin{array}{l}\text { Temporary } \\
\text { Contracts }\end{array}$ & $\begin{array}{l}\text { Trade Union } \\
\text { Coverage }\end{array}$ & $\begin{array}{l}\text { Unemployment } \\
\text { Benefits }\end{array}$ & $\begin{array}{l}\text { Tenure } \\
\text { Enhancing }\end{array}$ & $\begin{array}{l}\text { Wage } \\
\text { Compressing }\end{array}$ & $\begin{array}{l}\text { Total } \\
\text { Difference }\end{array}$ \\
\hline Southern & .360 & .002 & -.035 & .075 & .025 & -.002 & .042 & .023 & .066 \\
\hline Liberal & .349 & .066 & .080 & -.042 & -.023 & -.027 & .104 & -.050 & .055 \\
\hline Continental & .302 & .027 & -.024 & .007 & .023 & -.025 & .010 & -.002 & .008 \\
\hline Other & .278 & .033 & -.021 & .010 & -.060 & .022 & .022 & -.038 & -.016 \\
\hline Nordic & .247 & -.126 & -.017 & .008 & .025 & .062 & -.135 & .087 & -.048 \\
\hline Eastern & .183 & -.015 & -.041 & -.022 & -.035 & .001 & -.078 & -.034 & -.111 \\
\hline
\end{tabular}

Note: FAMILY GAP are the fitted values using the coefficients of a regression of the family gap against parental leave, job protection regulation, restrictions on the use of temporary contracts, trade union coverage, unemployment benefits and year dummies, but omitting the effect of year dummies. TOTAL DIFFERENCE is the log-points difference in the family gap between a specific group of countries and the average of all countries in our sample. 
Table 11 decomposes the impact of each one of the labor market institutions in determining the family gap in each group of countries. The table shows the log points difference between the family gap in one group of countries and the sample average due to each of the labor market institutions. The family gap in the first column is the fitted values of the family gap in a regression against parental leave, job protection regulation, restrictions on the use of temporary contracts, trade union coverage, unemployment benefits and year dummies, subtracting from the fitted value the effect of the year dummies. The contrast between the group of Liberal and Nordic countries is particularly interesting. The former are representative of flexible, unregulated labor markets with a relatively low level of almost all labor market institutions, with the exception of restrictions to temporary contracts. Instead, the Nordic countries are the typical example of regulated labor markets with a relatively high level of almost all the labor market institutions. Since the effect of the two groups of labor market policies on the family gap is of opposite sign, Liberal countries benefit from the relatively low level of wage compressing policies, but get hurt by the relatively low level of tenure enhancing policies. Just the opposite story can be said in relation to the group of Nordic countries. The group of Southern European countries displays the typical picture of dual labor markets, with two differentiated segments, one heavily protected by strict firing restrictions, and possibly by unions, and the other subject to temporary, easy to terminate, contracts. This particular combination of policies seems to be the worst in relation to the family gap, since both the relatively low level of tenure enhancing policies (mainly due to the lax regulation of temporary contracts) and the relatively high level of wage compressing policies contribute to the large gap in Southern European countries, which is $26 \%$ higher than the sample mean.

\section{Robustness Tests}

In tables 12 to 14 we test the robustness of our results throughout different specifications, by including additional controls and changing the way we compute the family gap. For comparison purposes, the first column in Table 12 and the first two columns in Table 13 present our earlier results. In Table 12 we show the magnitude of the family gap across different specifications of step 1 of our methodology (equations (1) and (2)). FAMILYGAP2 is the family gap 
estimated from individual earnings regressions on mothers and non-mothers including two additional controls that could be correlated with the family gap and the labor market institutions variables: a control for whether the mother stopped working around childbirth (JOBINTERRUPT) and a control for public sector employment (INPUBLIC). In FAMILYGAP2 the job interruption controls are allowed to vary by country, since the proportion of mothers that stop working around childbirth is potentially affected by the set of labor market regulations in each country. FAMILYGAP2 is then obtained from the following equation:

FAMILYGAP2 $_{j t}=$

$\left(\begin{array}{l}b_{0 N M j t}+b_{1 N M j t} P A R T_{N M U S t}+b_{2 N M j t} H R P A R T_{N M U S t}+b_{3 N M j t} H R F U L L_{N M U S t} \\ +X_{N M U S t} \cdot B_{N M j t}+I N P U B L I C_{N M U S t} \cdot I_{N M j t}\end{array}\right)$

$-\left(\begin{array}{l}b_{0 M j t}+b_{1 M j t} P A R T_{M U S t}+b_{2 M j t} H R P A R T_{M U S t}+b_{3 M j t} H R F U L L_{M U S t} \\ +X_{M U S t} \cdot B_{M j t}+K I D S_{M U S t} \cdot K_{M j t} \\ +J O B I N T E R R U P T_{M j t} \cdot J_{M j t}+I N P U B L I C_{M U S t} \cdot I_{M j t}\end{array}\right)$

where the coefficients are obtained from individual wage regressions such as, $\ln E A R N_{i j t}=b_{0 j t}+b_{1 j t} P A R T_{i j t}+b_{2 j t} H R P A R T_{i j t}+b_{3 j t} H R F U L L_{i j t}$ $+X_{i j t} \cdot B_{j t}+\operatorname{KIDS}_{i j t} \cdot K_{j t}+\operatorname{JOBINTERRUPT}_{i j t} \cdot J_{j t}+\operatorname{INPUBLIC}_{i j t} \cdot I_{j t}+e_{i j t}$

Finally, in the last column of the table, FAMILYGAP3 is the earnings gap between mothers and non-mothers assuming that mothers and non-mothers have the same levels of observable characteristics, except for the kids and job interruption controls which are mother specific:

FAMILYGAP3 ${ }_{j t}=$

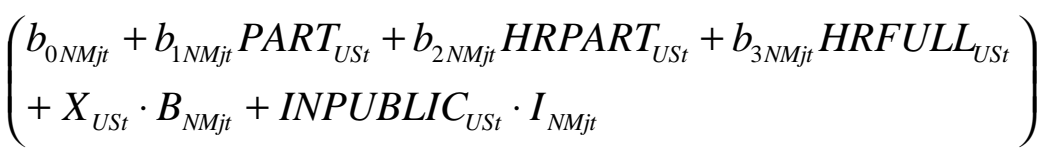

$-\left(\begin{array}{l}b_{0 M j t}+b_{1 M j t} P A R T_{U S t}+b_{2 M j i} H R P A R T_{U S t}+b_{3 M j t} H R F U L L_{U S t} \\ +X_{U S t} \cdot B_{M j t}+K I D S_{M U S t} \cdot K_{M j t} \\ +J O B I N T E R R U P T_{M j t} \cdot J_{M j t}+I N P U B L I C_{U S t} \cdot I_{M j t}\end{array}\right)$

According to FAMILYGAP3, given that mothers and non-mothers have the same levels of observable characteristics, the main reason for a family gap is that the returns to the same skills are different between mothers and nonmothers. 


\section{Table 12}

Family Gap in Pay. Different Specifications

\begin{tabular}{l|ccc}
\hline & $\begin{array}{c}(1) \\
\text { FAMILYGAP }\end{array}$ & $\begin{array}{c}(2) \\
\text { FAMILYGAP2 }\end{array}$ & FAMILYGAP3 \\
\hline Southern & .356 & .415 & .269 \\
Liberal & .319 & .319 & .190 \\
Continental & .243 & .268 & .155 \\
Nordic & .208 & .210 & .120 \\
Eastern & .140 & .103 & -.010 \\
Other & .106 & .246 & .069 \\
$\begin{array}{l}\text { Difference in } \\
\text { characteristics between } \\
\text { mothers and non-mothers }\end{array}$ & YES & YES & NO \\
JOBINTERRUPT & NO & YES & YES \\
INPUBLIC & NO & YES & YES \\
\hline
\end{tabular}

The numbers in Table 12 show that, when additional controls are included, the difference in the family gap across countries grows, with the gap increasing in countries with an already large family gap and decreasing in countries with a relatively low family gap. The ranking of countries remains the same, with Southern European countries showing the biggest wage penalty for mothers, followed by the group of Liberal countries, Continental European countries, and Nordic countries. Also, and as one should expect, the magnitude of the family gap falls in all groups of countries in column 3, when we remove the difference in observable characteristics between mothers and non-mothers. But still in the case of FAMILYGAP3, the ranking of countries is the same as before. Overall, the results in table 12 show that the difference in the family gap in pay across countries is quite robust to the specification changes in step 1 of our methodology.

In Table 13 we test the robustness of the results for step 2 across different specifications. In columns 2 and 3, we run regressions on the same vector of labor market institutions as before but now including as dependent variable FAMILYGAP2 and FAMILYGAP3, respectively. In column 4, we regress FAMILYGAP against an alternative measure of unemployment benefits (SOCIALSEC), trade union power (COLLREL), and job protection regulations (EMPLAW). These new measures of labor market institutions come from Botero et al., (2004). SOCIALSEC stands for Social Security Laws Index and measures social security benefits as the average of: (1) Old age, disability and death benefits; (2) Sickness and health benefits; and (3) Unemployment benefits. COLLREL stands for Collective Relations Law Index and measures the 
protection of collective relations laws as the average of: (1) Labor union power; and (2) Collective disputes. EMPLAW stands for Employment Laws Index, and measures the protection of labor and employment laws as the average of: (1) Alternative employment contracts; (2) Cost of increasing hours worked; (3) Cost of firing workers; and (4) Dismissal procedures.

Table 13

Results for various specifications. OLS regression

\begin{tabular}{|c|c|c|c|c|c|c|c|c|}
\hline & \multicolumn{2}{|c|}{$\begin{array}{c}(1) \\
\text { FAMILYGAP }\end{array}$} & \multicolumn{2}{|c|}{$\begin{array}{c}(2) \\
\text { FAMILYGAP2 }\end{array}$} & \multicolumn{2}{|c|}{$\begin{array}{c}(3) \\
\text { FAMILYGAP3 }\end{array}$} & \multicolumn{2}{|c|}{$\begin{array}{c}(4) \\
\text { FAMILYGAP }\end{array}$} \\
\hline & Coeff & $\mathrm{t}$ & Coeff & $t$ & Coeff & $t$ & Coeff & $\mathrm{t}$ \\
\hline UBENEFITS & .5898 & 1.23 & .8075 & 1.56 & .3942 & .63 & & \\
\hline COVERAGE & .0013 & 1.20 & .0014 & 1.17 & .0015 & 1.01 & & \\
\hline PROTREG & -.0633 & -2.01 & -.0620 & -1.82 & -.0545 & -1.34 & & \\
\hline RESTRICTEMP & -.0258 & -1.61 & -.0442 & -2.54 & -.0385 & -1.85 & -.0181 & -1.03 \\
\hline LVWEEKS & -.0045 & -1.99 & -.0058 & -2.36 & -.0033 & -1.12 & -.0054 & -2.47 \\
\hline SOCIALSEC & & & & & & & .9778 & 2.54 \\
\hline COLLREL & & & & & & & .0287 & .13 \\
\hline EMPLAW & & & & & & & -.1051 & -.58 \\
\hline $\mathrm{R} 2$ & \multicolumn{2}{|c|}{.40} & \multicolumn{2}{|c|}{.49} & \multicolumn{2}{|c|}{.35} & \multicolumn{2}{|c|}{.32} \\
\hline $\begin{array}{l}\text { Difference in } \\
\text { characteristics } \\
\text { between mothers and } \\
\text { non-mothers }\end{array}$ & \multicolumn{2}{|c|}{ YES } & \multicolumn{2}{|c|}{ YES } & \multicolumn{2}{|c|}{ NO } & \multicolumn{2}{|c|}{ YES } \\
\hline JOBINTERRUPT & \multicolumn{2}{|c|}{ NO } & \multicolumn{2}{|c|}{ YES } & \multicolumn{2}{|c|}{ YES } & \multicolumn{2}{|c|}{ NO } \\
\hline INPUBLIC & \multicolumn{2}{|c|}{ NO } & \multicolumn{2}{|c|}{ YES } & \multicolumn{2}{|c|}{ YES } & \multicolumn{2}{|c|}{ NO } \\
\hline
\end{tabular}

The numbers in Table 13 show that the effect of labor market institutions on the family gap is very robust to changes in the specification of the dependent and independent variables. When additional controls are included (FAMILYGAP2), the fit of the model improves and both the significance and the magnitude of the coefficients grow. Under this specification, we are able now to explain $49 \%$ of the variation of the family gap across time and countries. In the case of FAMILYGAP3, not surprisingly, the magnitude and significance of the coefficients fall (we are removing differences in observables between mothers and non-mothers as a source for the gap) but wage compressing institutions continue to be associated to a bigger family gap and tenure enhancing institutions to a lower one. In column 4 , the new measures of labor market institutions have a similar impact on the family gap as the ones they replace, with a particularly strong effect for the SOCIALSEC variable. It should be noted, that these new measures of institutions are aggregates of measures that we previously disaggregated (for example, the EMPLAW measure is an average 
of job protection and restrictions to the use of alternative - possibly temporary contracts), so it is not surprising that the fit of the model and the significance of the coefficients fall in column 4 compared to the other columns.

Table 14

Results for the Southern effect. OLS regressions

\begin{tabular}{|c|c|c|c|c|c|c|c|c|}
\hline & \multicolumn{8}{|c|}{ FAMILYGAP } \\
\hline & Coeff & t. (SE) & Coeff & t. (SE) & Coeff & t. (SE) & Coeff & t. (SE) \\
\hline LVWEEKS & & & -.0014 & $\begin{array}{l}-.83 \\
(.0017)\end{array}$ & -.0014 & $\begin{array}{l}-.82 \\
(.0017)\end{array}$ & -.0042 & $\begin{array}{l}-1.85 \\
(.0023)\end{array}$ \\
\hline PROTREG & -.0700 & $\begin{array}{l}-2.84 \\
(.0246)\end{array}$ & -.0605 & $\begin{array}{l}-2.12 \\
(.0285)\end{array}$ & -.0612 & $\begin{array}{l}-2.08 \\
(.0294)\end{array}$ & -.0653 & $\begin{array}{l}-2.06 \\
(.0316)\end{array}$ \\
\hline RESTRICTEMP & & & & & -.0026 & $\begin{array}{l}-.17 \\
(.0153)\end{array}$ & -.0151 & $\begin{array}{l}-.76 \\
(.0200)\end{array}$ \\
\hline COVERAGE & & & & & & & .0013 & $\begin{array}{l}1.14 \\
(.0011)\end{array}$ \\
\hline UBENEFITS & & & & & & & .6042 & $\begin{array}{l}1.26 \\
(.4801)\end{array}$ \\
\hline SOUTHERN & .1707 & $\begin{array}{l}2.32 \\
(.0736)\end{array}$ & .1643 & $\begin{array}{l}2.18 \\
(.0755)\end{array}$ & .1562 & $\begin{array}{l}1.73 \\
(.0901)\end{array}$ & .0874 & $\begin{array}{l}.89 \\
(.0984)\end{array}$ \\
\hline Year dummies & YES & YES & YES & YES & YES & YES & YES & YES \\
\hline Sample size & 40 & & 38 & & 38 & & 32 & \\
\hline $\mathrm{R} 2$ & .28 & & .31 & & .32 & & .42 & \\
\hline
\end{tabular}

Note - LWWEEKS is the number of weeks for parental leave. PROTREG is the index of strictness of protection of regular jobs. RESTRICTEMP is an index of how difficult is for firms to hire workers under temporary contracts (the higher the index the more difficult this is). COVERAGE is the percentage of employees affected directly or indirectly by trade union arrangements. UBENEFITS is an index measuring the generosity of social benefits to the unemployed. SOUTHERN is a dummy variable with value 1 for Portugal, Spain and Italy.

Since the family gap in Southern European countries is remarkably bigger than anywhere else across all specifications, in Table 14 we test the robustness of our previous results to the inclusion of a Southern Effect. It is possible, for example, that cultural factors explain the relatively large family gap in Southern European countries. If these cultural factors are correlated with the set of labor market institutions in these countries, then it is possible that all we are doing is to capture a Southern effect through the coefficients on the labor market institutions variables. We ask, then, to what extent our previous results are driven by extreme values of the Southern European countries. Table 14 indicates that as more variables are included in the specification, both the magnitude and the significance of the Southern effect fall. In the last specification, considering all the labor market institutions, the Southern effect loses its significance and, 
with the exception of RESTRICTEMP, the magnitude and significance of the labor market institutions controls remains remarkably similar to the ones we obtained before. The table suggests, then, that the Southern effect is nothing else than the combined effect of the set of labor market policies in Southern European countries.

\section{Conclusions}

In this paper we have estimated the family gap in thirty five countries and have looked and the role of labor market institutions in explaining the cross-country differences in this gap. Our approach has been based on the hypothesis that a distinguishing feature of mothers is their need to transition in and out of the labor market around childbirth and that labor market institutions affect both the probability and the length on such transitions.

We have found that the wage penalty associated to motherhood varies significantly across countries. We found that mothers in Southern Europe suffer a wage penalty up to two times as large as mothers in Nordic countries.

An important result of this study is that there is not much of a relation between the family and the gender gaps across countries. We found that often labor market institutions have opposite effects on these two sources of wage inequality and that hence the task of designing optimal policies to reduce both is not straightforward. In particular, our results indicate that protecting mothers against contract termination, either by use of parental leave or job protection regulations, would be the most effective way of reducing the earnings gap between mothers and non-mothers but also between men and women. Instead, policies traditionally associated to wage compression, although effective at lowering the gender gap, might lead to an increase in the wage gap between mothers and women without children. Our interpretation of these results is that an important reason mothers lag behind other women in terms of earnings is the loss of accumulated job market experience due to job transitions around childbirth. Furthermore, to the extent many women are also mothers, this is also an important reason for the wage gap between women and men. 
Finally, we compared and ranked groups of countries according to the magnitude of the family and the gender gaps. We found that mothers in Southern European countries suffer the highest family gap, although the gender gap is relatively low there. An important research question is how much of the extremely low fertility rates in Southern European countries (Adserà 2004, Del Boca et al 2003) can be explained by the high family gap. Also, the data we used in this study is cross-sectional and hence is not well suited to study in detail the frequency and length of job transitions that mothers go through around childbirth. Longitudinal datasets would be the natural alternative and we think that an important research topic is to look in more detail at the impact of labor market institutions on job transitions by mothers. 


\section{Appendix: Data}

\begin{tabular}{|c|c|c|c|c|c|c|c|c|c|c|c|c|c|c|}
\hline & \multicolumn{8}{|c|}{ TENURE ENHANCING POLICIES } & \multicolumn{6}{|c|}{ WAGE COMPRESSING POLICIES } \\
\hline & \multirow{2}{*}{$\begin{array}{l}\text { LVWEEKS } \\
\text { (weeks) } 1 \\
1999-01\end{array}$} & \multirow{2}{*}{$\begin{array}{l}\text { LVREP } \\
\begin{array}{l}(\%) 1 \\
1999- \\
01\end{array}\end{array}$} & \multicolumn{3}{|c|}{$\begin{array}{l}\text { PROTREG } \\
\text { (index)2 }\end{array}$} & \multicolumn{3}{|c|}{$\begin{array}{l}\text { RESTRICTEMP } \\
\text { (index)3 }\end{array}$} & \multicolumn{3}{|c|}{$\begin{array}{l}\text { COVERAGE } \\
(\%) 4\end{array}$} & \multirow{2}{*}{$\begin{array}{l}\text { UBENEFITS } \\
\text { (index) } 5 \\
90 \mathrm{~s}\end{array}$} & \multicolumn{2}{|c|}{$\begin{array}{l}\text { MINWAGE } \\
(\%) 6\end{array}$} \\
\hline & & & $80 s$ & $90 \mathrm{~s}$ & $00 \mathrm{~s}$ & $80 \mathrm{~s}$ & $90 \mathrm{~s}$ & 00s & $80 s$ & $90 \mathrm{~s}$ & 00s & & 1986 & 2000 \\
\hline SOUTHERN & 20.6 & 93.3 & 3.5 & 2.9 & 2.9 & 0.9 & 1.6 & 2.0 & 70.0 & 73.3 & 80.0 & 0.80 & 0.53 & 0.35 \\
\hline CONTINENTAL & 15.5 & 95.4 & 2.3 & 2.3 & 2.3 & 2.3 & 2.6 & 2.6 & 77.5 & 79.1 & 77.1 & 0.75 & 0.58 & 0.52 \\
\hline LIBERAL & 8.0 & 28.5 & 0.9 & 1.1 & 1.2 & 3.5 & 3.5 & 3.3 & 59.0 & 49.5 & 37.25 & 0.71 & 0.48 & 0.47 \\
\hline NORDIC & 47.0 & 83.2 & 2.3 & 2.2 & 2.2 & 1.8 & 2.6 & 2.6 & 77.5 & 77.5 & 82.5 & 0.89 & 0.59 & NA \\
\hline EASTERN & 24.5 & 89.7 & NA & 2.7 & 2.7 & NA & 1.5 & 1.4 & NA & NA & 36.2 & 0.81 & NA & 0.40 \\
\hline OTHER & 13.0 & 80.0 & 2.4 & 2.3 & 2.3 & 0.28 & 0.31 & 0.37 & 25.0 & 20.0 & 15.0 & 0.51 & 0.29 & 0.33 \\
\hline
\end{tabular}

SOUTHERN countries are Portugal, Italy and Spain. CONTINENTAL countries are Austria, Belgium, France, Netherlands, W. Germany and Switzerland. LIBERAL countries are Australia, Ireland, New Zealand, U.K. and U.S. NORDIC countries are Denmark, Finland, Norway and Sweden. EASTERN countries are the Czech Republic, E. Germany, Latvia, Slovak Republic, Hungary, Bulgaria, Poland, Russia and Slovenia. OTHER countries are Brazil, Chile, Cyprus, Israel, Japan, Mexico, Philippines and Taiwan.

1 LVWEEKS is the number of weeks for parental leave. LVREP is the replacement rate during parental leave. Source: O.E.C.D. Employment Outlook (2001). Data is for the 1999-2001 period.

2PROTREG is the index of strictness of protection of regular jobs; the higher the index, the stricter the protection against the dismissal of workers in regular jobs. Source:

O.E.C.D. Employment Outlook (2004).

3RESTRICTEMP is an index of how difficult is for firms to hire workers under temporary contracts. It indicates the number of valid cases for temporary contracts other than the usual objective reasons; the higher the index the more difficult is for firms to use temporary contracts. Source: O.E.C.D. Employment Outlook (2004).

4COVERAGE is the percentage of employees affected directly or indirectly by trade union arrangements. Source: O.E.C.D. Employment Outlook (2004).

5UBENEFITS is a one-time index of the generosity of unemployment benefits, combining information on the replacement rate and the duration of unemployment benefits. The higher the index the more generous unemployment benefits are. Source: Botero et al., (2004).

6MINWAGE is the ratio of the minimum wage to the average wage in each country. Source: O.E.C.D. Minimum Wage Database. 


\begin{tabular}{|c|c|c|c|c|c|c|c|c|c|c|c|c|c|c|}
\hline & $\begin{array}{l}\text { LVWEEKS } \\
\text { (weeks) }\end{array}$ & $\begin{array}{l}\text { LVREP } \\
(\%)\end{array}$ & \multicolumn{3}{|c|}{$\begin{array}{c}\text { PROTREG } \\
\text { (index) }\end{array}$} & \multicolumn{3}{|c|}{$\begin{array}{l}\text { RESTRICTEMP } \\
\text { (index) }\end{array}$} & \multicolumn{3}{|c|}{$\begin{array}{c}\text { COVERGAE } \\
(\%)\end{array}$} & \multirow{2}{*}{$\begin{array}{c}\text { UBENEFITS } \\
\text { (index) } \\
90 \mathrm{~s}\end{array}$} & \multicolumn{2}{|c|}{$\begin{array}{l}\text { MINWAGE } \\
(\%)\end{array}$} \\
\hline & 1999-01 & $1999-01$ & $80 S$ & $90 \mathrm{~S}$ & OOS & $80 s$ & $90 \mathrm{~s}$ & 00s & $80 s$ & $90 \mathrm{~s}$ & 00s & & 1986 & 2000 \\
\hline Australia & 0.00 & 0.00 & 1.00 & 1.50 & 1.50 & 3.50 & 3.50 & 3.50 & 80.00 & 80.00 & 80.00 & 0.79 & 0.63 & 0.58 \\
\hline Austria & 16.00 & 100.00 & 2.90 & 2.90 & 2.40 & 2.75 & 2.75 & 2.75 & 95.00 & 95.00 & 95.00 & 0.63 & & \\
\hline Brasil & & & & & & & & & & & & 0.56 & & \\
\hline Bulgaria & & & & & & & & & & & & 0.84 & & \\
\hline Chile & & & & & & & & & & & & 0.73 & & \\
\hline Cyprus & & & & & & & & & & & & & & \\
\hline Czech & 28.00 & 69.00 & & 3.30 & 3.30 & & 3.25 & 3.25 & & & 25.00 & 0.74 & & 0.31 \\
\hline Denmark & 30.00 & 100.00 & 1.50 & 1.50 & 1.50 & 2.25 & 3.25 & 3.25 & 70.00 & 70.00 & 80.00 & 0.90 & 0.62 & \\
\hline Finland & 52.00 & 70.00 & 2.80 & 2.30 & 2.20 & 2.50 & 2.50 & 2.50 & 90.00 & 90.00 & 90.00 & 0.91 & & \\
\hline Flanders & 15.00 & 77.00 & 1.70 & 1.70 & 1.70 & 1.00 & 2.25 & 2.25 & 90.00 & 90.00 & 90.00 & 0.86 & 0.57 & 0.49 \\
\hline France & 16.00 & 100.00 & 2.30 & 2.30 & 2.50 & 1.75 & 1.50 & 1.50 & 80.00 & 90.00 & 90.00 & 0.82 & 0.63 & 0.62 \\
\hline GermanyE & & & & & & & & & & & & & & \\
\hline GermanyW & 14.00 & 100.00 & 2.60 & 2.70 & 2.70 & 2.00 & 2.75 & 2.75 & 80.00 & 80.00 & 68.00 & 0.78 & 0.59 & \\
\hline Hungary & 24.00 & 100.00 & . & 1.90 & 1.90 & & 3.25 & 3.25 & & & 30.00 & 0.78 & & 0.50 \\
\hline Ireland & 14.00 & 70.00 & 1.60 & 1.60 & 1.60 & 3.50 & 3.50 & 3.25 & & & & 0.76 & & 0.56 \\
\hline Israel & & & & & & & & & & & & 0.85 & & \\
\hline Italy & 21.50 & 80.00 & 1.80 & 1.80 & 1.80 & 0.25 & 1.00 & 2.50 & 80.00 & 80.00 & 80.00 & 0.73 & 0.75 & \\
\hline Japan & 14.00 & 60.00 & 2.40 & 2.40 & 2.40 & 2.00 & 2.25 & 2.75 & 25.00 & 20.00 & 15.00 & 0.82 & 0.29 & 0.33 \\
\hline Latvia & & & & & & & & & & & & 0.80 & & \\
\hline Mexico & 12.00 & 100.00 & & 2.30 & 2.30 & 0.25 & 0.25 & 0.25 & & & & 0.00 & & \\
\hline Netherlands & 16.00 & 100.00 & 3.10 & 3.10 & 3.10 & 3.00 & 3.25 & 3.25 & 70.00 & 70.00 & 80.00 & 0.68 & 0.56 & 0.47 \\
\hline NewZEaland & & & & 1.40 & 1.70 & 3.50 & 3.50 & 3.00 & 60.00 & 60.00 & 25.00 & 0.56 & 0.47 & 0.46 \\
\hline Norway & 42.00 & 100.00 & 2.30 & 2.30 & 2.30 & 1.25 & 1.50 & 1.50 & 70.00 & 70.00 & 70.00 & 0.82 & & \\
\hline Philippines & & & & & & & & & & & & 0.00 & & \\
\hline Poland & 18.00 & 100.00 & & 2.20 & 2.20 & & 3.50 & 2.50 & & & 40.00 & 0.83 & & 0.38 \\
\hline Portugal & 24.30 & 100.00 & 4.80 & 4.30 & 4.30 & 1.50 & 2.00 & 2.00 & 70.00 & 70.00 & 80.00 & 0.85 & 0.47 & 0.38 \\
\hline Russia & & & & & & & & & & & & 0.90 & & \\
\hline Slovak & 28.00 & 90.00 & & 3.60 & 3.50 & & 3.25 & 3.50 & & & 50.00 & 0.79 & & 0.41 \\
\hline Slovenia & & & & & & & & & & & & 0.86 & & \\
\hline Spain & 16.00 & 100.00 & 3.90 & 2.60 & 2.60 & 1.00 & 2.00 & 1.75 & 60.00 & 70.00 & 80.00 & 0.81 & 0.37 & 0.32 \\
\hline
\end{tabular}




\begin{tabular}{|c|c|c|c|c|c|c|c|c|c|c|c|c|c|c|}
\hline & $\begin{array}{l}\text { LVWEEKS } \\
\text { (weeks) }\end{array}$ & $\begin{array}{l}\text { LVREP } \\
(\%)\end{array}$ & \multicolumn{3}{|c|}{$\begin{array}{c}\text { PROTREG } \\
\text { (index) }\end{array}$} & \multicolumn{3}{|c|}{$\begin{array}{l}\text { RESTRICTEMP } \\
\text { (index) }\end{array}$} & \multicolumn{3}{|c|}{$\begin{array}{c}\text { COVERGAE } \\
(\%)\end{array}$} & $\begin{array}{l}\text { UBENEFITS } \\
\text { (index) }\end{array}$ & \multicolumn{2}{|c|}{$\begin{array}{l}\text { MINWAGE } \\
(\%)\end{array}$} \\
\hline Sweden & 64.00 & 63.00 & 2.90 & 2.90 & 2.90 & 1.00 & 3.25 & 3.25 & 80.00 & 80.00 & 90.00 & 0.94 & 0.57 & \\
\hline Swiss & 16.00 & & 1.20 & 1.20 & 1.20 & 3.50 & 3.50 & 3.50 & 50.00 & 50.00 & 40.00 & 0.74 & & \\
\hline Taiwan & & & & & & & & & & & & 0.67 & & \\
\hline Uk & 18.00 & 44.00 & 0.90 & 0.90 & 1.10 & 3.50 & 3.50 & 3.50 & 70.00 & 40.00 & 30.00 & 0.78 & 0.46 & 0.42 \\
\hline US & 0.00 & 0.00 & 0.20 & 0.20 & 0.20 & 3.50 & 3.50 & 3.50 & 26.00 & 18.00 & 14.00 & 0.66 & 0.37 & 0.36 \\
\hline
\end{tabular}

Notes:

SOUTHERN countries are Portugal, Italy and Spain. CONTINENTAL countries are Austria, Belgium, France, Netherlands, W. Germany and Switzerland. LIBERAL countries are Australia, Ireland, New Zealand, U.K. and U.S. NORDIC countries are Denmark, Finland, Norway and Sweden. EASTERN countries are the Czech Republic, E. Germany, Latvia, Slovak Republic, Hungary, Bulgaria, Poland, Russia and Slovenia. OTHER countries are Brazil, Chile, Cyprus, Israel, Japan, Mexico, Philippines and Taiwan.

1 LVWEEKS is the number of weeks for parental leave. LVREP is the replacement rate during parental leave. Source: O.E.C.D. Employment Outlook (2001). Data is for the 1999-2001 period.

2PROTREG is the index of strictness of protection of regular jobs; the higher the index, the stricter the protection against the dismissal of workers in regular jobs. Source: O.E.C.D. Employment Outlook (2004).

3RESTRICTEMP is an index of how difficult is for firms to hire workers under temporary contracts. It indicates the number of valid cases for temporary contracts other than the usual objective reasons; the higher the index the more difficult is for firms to use temporary contracts. Source: O.E.C.D. Employment Outlook (2004).

4COVERAGE is the percentage of employees affected directly or indirectly by trade union arrangements. Source: O.E.C.D. Employment Outlook (2004).

5 UBENEFITS is a one-time index of the generosity of unemployment benefits, combining information on the replacement rate and the duration of unemployment benefits. The higher the index the more generous unemployment benefits are. Source: Botero et al., (2004).

6MINWAGE is the ratio of the minimum wage to the average wage in each country. Source: O.E.C.D. Minimum Wage Database. 


\section{References}

Adserà A. (2004), "Changing Fertility Rates in Developed Countries. The Impact of Labor Market Institutions," Journal of Population Economics, Vol. 17 No. 1, pp. 17.43.

Altûg S. and Miller R. (1998), "The Effect of Work Experience on Female Wages and Labour Supply," Review of Economic Studies, Vol. 65(1), pp. 45-85.

Anderson D., Binder M., and Krause K. (2003), "The Motherhood Wage Penalty Revisited: Experience, Heterogeneity, Work Effort, and Work-Schedule Flexibility," Industrial and Labor Relations Review, Vol. 56, pp. 273-94.

Blau F., and Kahn F. (2003), "Understanding International Differences in the Gender Pay Gap," Journal of Labor Economics, Vol. 21 No. 1, pp. 106-44.

Botero J., Djankov S., La Porta R., Lopez-de-Silanes F., and Shleifer A. (2004), "The Regulation of Labor," Quarterly Journal of Economics, Vol. 119, pp. 1339-82.

Datta G., and Smith N. (2002), "Children and Career Interruptions: The Family Gap in Denmark," Economica, Vol. 69(276), pp. 609-29.

Davies R., and Pierre G. (2005), "The Family Gap in Pay in Europe: A Cross-Country Study," Labour Economics, Vol. 12, pp. 469-86.

Del Boca D., Pasqua S., and Pronzato C. (2003), “Analyzing Women's Employment and Fertility Rates in Europe: Differences and Similarities in Northern and Southern Europe", Centre for Household, Income, Labour and Demographic Economics, University of Torino, Italy.

Dolado J., Jansen M., and Jimeno J. (2005), "Dual Employment Protection Legislation: A Framework for Análisis," CEPR Discusión Papers, No. 5033.

Eckstein Z. and Wolpin K. (1989), "Dynamic Labour Force Participation of MarriedWomen and EndogenousWork Experience," Review of Economic Studies, Vol. 56(3), pp. 375-90.

Erosa A., Fuster L., and Restuccia D. (2002), "Fertility Decisions and Gender Differences in Labor Turnover, Employment, and Wages," Review of Economic Dynamics, Vol. 5 No. 4, pp. 856-91.

Gornick J.C., Meyerrs M.K., and Ross K.E. (1997), "Supporting the Employment of Mothers: Policy Variation Across Fourteen Welfare States," Journal of European Social Policy, Vol. 7, pp. 45-70.

Gronau R. (1988), “Sex-Related Wage Differentials and Women's Interrupted Careers-The Chicken or the Egg," Journal of Labor Economics, Vol. 6 (3), pp 277-301.

Harkness S. and Waldfogel J. (1999), The Family Gap in Pay: Evidence from Seven Industrialized Countries, Centre for Analysis of Social Exclusion, Working Paper No. 219.

I.N.E. (2006), Instituto nacional de Estadística, Indicadores Demográficos Básicos (IDB).

I.N.E. (2006), Instituto Nacional de Estadística, Encuesta de Población Activa - 1976-2005.

Klerman, J. and Leibowitz A. (1994), "The Work-Employment Distinction Among New Mothers," Journal of Human Resources, Vol. 29(2), pp. 277-303.

Korenman S. and Neumark D. (1992), "Marriage, Motherhood, and Wages," Journal of Human Resources, Vol. 27(2), pp. 233-55. 
Lindbeck A., and Snower D. (2001), "Insiders versus Outsiders," Journal of Economic Perspectives, Vol. 15 No. 1, pp. 165-88.

Lundberg S., and Rose E. (2000), "Parenthood and the Earnings of Married Men and Women," Labour Economics, Vol. 7, pp. 689-710.

Millimet D. (2000), "The Impact of Children on Wages, Job Tenure, and the Division of Household Labour," Economic Journal, Vol. 110(462), pp. 139-57.

Nickell S. (1997), "Unemployment and Labor Market Rigidities: Europe versus North America," The Journal of Economic Perspectives, Vol. 11 No. 3, 55-74.

O.E.C.D., (2001), O.E.C.D. Employment Outlook, 2001.

O.E.C.D., (2004), O.E.C.D. Employment Outlook, 2004.

O.E.C.D. (2005), O.E.C.D. in Figures, 2005.

Phipps S., Burton P., and Lethbridge L. (2001), "In and Out of the Labour Market: Long-Term Income Consequences of Child-Related Interruptions to Women's Paid Work," Canadian Journal of Economics, Vol. 34(2), pp. 411-29.

Siebert H. (1997), "Labor Market Rigidities: At the Root of Unemployment in Europe," The Journal of Economic Perspectives, Vol. 11 No. 3, pp. 37-54.

Sigle-Rushton W., and Waldfogel J. (2004), Family Gaps in Income: A Cross-National Comparison, Luxembourg Income Study Working Paper No. 382.

Todd E. (2001), Educational Attainment and Family Gaps in Women's Wages: Evidence from Five Industrialized Countries, Luxembourg Income Study Working Paper No. 246.

Topel R. and Ward M. (1992), Job Mobility and the Careers of Young Men, Quarterly Journal of Economics, Vol. 107(2), pp. 439-79.

Waldfogel J. (1995), "The Price of Motherhood: Family Status and Women's Pay in a Young British Cohort," Oxford Economic Papers, Vol. 47 No. 4, pp. 584-610.

Waldfogel J. (1998), "The Family Gap for Young Women in the United States and Britain: Can Maternity Leave Make a Difference?," Journal of Labor Economics, Vol. 16 No. 3, pp. 505-45.

Waldfogel J. (1998b), "Understanding the Family Gap in Pay for Women with Children," The Journal of Economic Perspectives, Vol. 12 No. 1, pp. 137-56. 